\title{
Chapter 12 \\ Climate Change and the Rise of the Central Asian Silk Roads
}

\author{
Daniel J. Hill
}

\begin{abstract}
The final centuries BCE (Before Common Era) saw the main focus of trade between the Far East and Europe switch from the so called Northern Route across the Asian steppes to the classical silk roads. The cities across central Asia flourished and grew in size and importance. While clearly there were political, economic and cultural drivers for these changes, there may also have been a role for changes in climate in this relatively arid region of Asia. Analysis of a new ensemble of snapshot global climate model simulations, run every 250 years over the last 6000 years, allows us to assess the long term climatological changes seen across the central Asian arid region through which the classical Silk Roads run. While the climate is comparatively stable through the Holocene, the fluctuations seen in these simulations match significant cultural developments in the region. From 1500 BCE the deterioration of climate from a transient precipitation peak, along with technological development and the immigration of Aryan nomads, drove a shift towards urbanization and probably irrigation, culminating in the founding of the major cities of Bukhara and Samarkand around 700-500 BCE. Between 1000 and 250 BCE the modelled precipitation in the central Asian arid region undergoes a transition towards wetter climates. The changes in the Western Disturbances, which is the key weather system for central Asian precipitation, provides $10 \%$ more precipitation and the increased hydrological resources may provide the climatological foundation for the golden era of Silk Road trade.
\end{abstract}

Keywords Silk roads $\cdot$ Climate change $\cdot$ Climate model $\cdot 6000$ years Precipitation

D. J. Hill ( $₫)$

School of Earth and Environment, University of Leeds, Leeds LS2 9JT, UK

e-mail: d.j.hill@leeds.ac.uk

L. E. Yang et al. (eds.), Socio-Environmental Dynamics along the Historical Silk Road, https://doi.org/10.1007/978-3-030-00728-7_12 


\subsection{Introduction}

Climate has changed throughout the course of the human civilization (Mayewski et al. 2004). The last 6000 years has seen significant climatic and precipitation changes, which have been well documented from both proxy records and modelling studies (Braconnot et al. 2004; Harrison et al. 2014). However, the relationship between these broad-scale, long-term changes in climate and the local environmental impacts is little understood, despite the major disruptions to ancient civilizations across Asia and Africa these have been implicated in (Butzer 2012). Across the world major civilizations have responded to climate change, from Africa (Welc and Marks 2014), Europe (Büntgen et al. 2011; Drake 2012), Asia (Staubwasser et al. 2003; Dong et al. 2012), the New World (Kennett et al. 2012) and maybe even the colonization of the Pacific Islands (Anderson et al. 2006). As well as driving civilization collapse, climate change could affect societal structures, polities and trade routes, particularly in the Silk Road region, where a complex network of trading routes cross the central Asian dry region.

Central Asia has been continuously inhabited for thousands of years and was home to thriving late Bronze Age cultures, including the Oxus Civilization (LambergKarlovsky 2013) and Sapalli culture (Kaniuth 2007). The city of Samarkand was founded around 600 BCE (Grenet 2002) and this may be associated with drying of central Asia and the initiation of irrigation of the Samarkand Oasis (Malatesta et al. 2012). Although there is evidence for settlement in the region of Bokhara from $3000 \mathrm{BCE}$, the city itself was founded around $500 \mathrm{BCE}$ as part of the Achaemenid Empire or first Persian Empire (Lo Muzio 2009). Trade along the classical Silk Road accelerated greatly with the rise of the Han Dynasty in China in the second century $\mathrm{BCE}$ and continued, with only minor interruption during the rise and fall of empires, for almost 2000 years until the collapse of the Safavid Empire in the 1720s (Faroqhi 1994).

Trade in precious materials, such as lapis lazuli, between the great civilizations of the Bronze Age, shows evidence of 4th millennium BCE trade, at least in sections of the classical Silk Roads (Herrmann 1968). However, the main exchange of goods, technologies and culture across Eurasia seems to have accompanied the move to mobile pastoralism in the vast Eurasian steppe region (Christian 2000). Central Asia hosted a unique Bronze Age culture, the Oxus Civilization, with established contacts with surrounding cultures in Mesopotamia and the Indus Valley (Lamberg-Karlovsky 2013) between roughly 2200 and 1700 BCE. Although the demise of central Asian Bronze Age cultures has not been extensively investigated, two hypotheses have been put forward for the collapse of the Oxus Civilization. Firstly, reduced hydrological resources and the demise of the agricultural canal system (Salvatori 2008), suggests a climatological driver for collapse. Whilst the second hypothesis, the increasing influence and hostile advance of pastoral nomads (Cattani 2008), suggests more cultural forces at work. Despite the interconnected nature of Bronze Age Eurasia, it was only after Chinese expansion in the second century BCE that a continuous connection was established across Asia from China to the Mediterranean (McNeill 


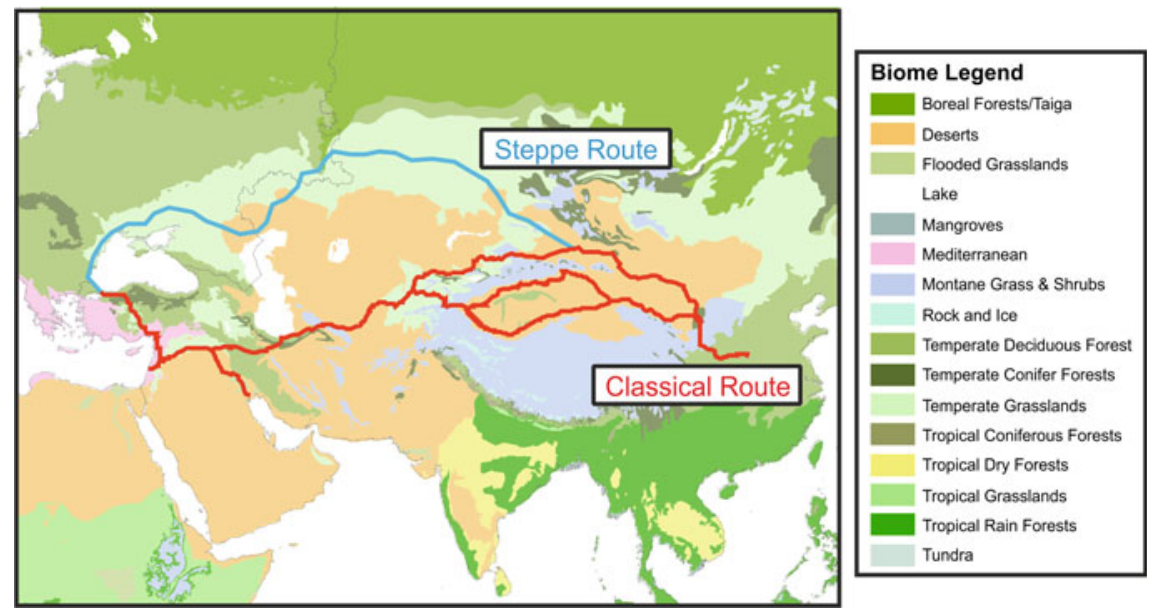

Fig. 12.1 Map of Central Asia, showing the biomes (Olson et al. 2001) and the older trade route of the Northern or Steppe Route (blue) and Classical Silk Roads (red)

1998). This seems to have shifted the main route of trade across Eurasia from the steppe to central Asian trade routes (Fig. 12.1), which in the late nineteenth century would become known as the Silk Roads (Christian 2000). This paper will investigate the evolution of climate of central Asia over the last 6000 years, using a climate model and investigate its impact on the changing trade, cultural and settlement patterns along the Silk Roads of Central Asia.

\subsection{Methods}

\subsubsection{Climate Model}

The HadCM3 version of the UK Met Office's Unified Model (Gordon et al. 2000), used in this study, is a fully coupled ocean-atmosphere General Circulation Model (GCM). It incorporates an atmospheric model with a resolution of $3.75^{\circ} \times 2.5^{\circ}$ with 19 levels in a hybrid vertical coordinate and an ocean model of $1.25^{\circ} \times 1.25^{\circ}$ with 20 levels (Cox 1984). Among the improvements in this version of the model are the simulation of convection (Gregory et al. 1997), orographic drag (Milton and Wilson 1996), the gravity wave drag scheme (Gregory et al. 1998) and the mixed phase cloud parameterizations (Gregory and Morris 1996). The land surface scheme incorporates the TRIFFID Dynamic Global Vegetation Model (Cox 2001), which is run coupled to the HadCM3 climate model.

GCMs have a long history of simulating global climate and have shown great skill in simulating modern day climate and palaeoclimatic change (Braconnot et al. 
2012; McMahon et al. 2015). Asian climate is dominated by the monsoonal regimes originating in the tropical Indian and Pacific Oceans. HadCM3 has been shown to perform skilfully in reproducing these monsoons and climate across Asia (Inness and Slingo 2003; Turner et al. 2005). The HadCM3 model has also been shown to be able to produce realistic representations of the Western Disturbance weather systems that dominate rainfall totals in central Asia and simulate changes in weather patterns in line with other similar GCM models (Ridley et al. 2013). As is a common feature of modelled precipitation, different GCMs predict different sensitivity of regional rainfall to increased greenhouse gas forcing, but the increases seen in future warming scenarios from HadCM3 are at least in line with the observational record (Dash et al. 2009).

\subsubsection{Methodology}

This study uses an ensemble of HadCM3 simulations covering the last 6000 years. This consists of 25 snapshot simulations, with boundary conditions appropriate to every 250 years between 6000 years B.P. and 250 years ago, with a final simulation using the full standard pre-industrial boundary conditions. Each of the simulations was initialized from an existing pre-industrial simulation and run for 250 years to allow the model to respond to the altered greenhouse gas and orbital forcing. Climatological means were taken from the last 50 years of the simulations.

\subsubsection{Boundary Conditions}

These simulations incorporate greenhouse gases and orbital forcing changes over the last 6000 years (Fig. 12.2), but otherwise the model boundary conditions are kept the same as standard HadCM3 pre-industrial simulations. Greenhouse gases are taken from ice core measurements, carbon dioxide (Monnin et al. 2004) and nitrogen dioxide (Flückiger et al. 2002) exclusively from the EPICA (European Project for Ice Coring in Antarctica) Dome C Antarctic ice core. Methane is taken to be the mean of the EPICA and GRIP (Greenland Ice Core Project) ice cores (Blunier et al. 1995; Flückiger et al. 2002), as it is not well mixed in the atmosphere. Orbital parameters are calculated from the orbital solutions of Laskar et al. (2004).

\subsection{Modelling Results}

The central Asian region has undergone significant changes in precipitation over the last 6000 years. This is reflected in this ensemble of HadCM3 simulations, where an $18 \%$ increase in mean annual precipitation is seen across a broad swathe of the central 


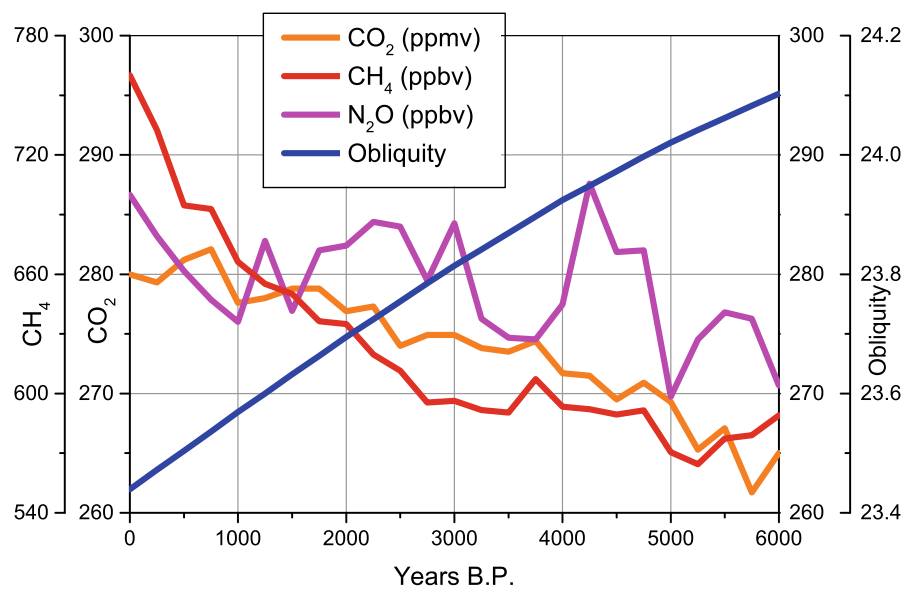

Fig. 12.2 Parameters used in each of the snapshot simulations in the ensemble for the last 6000 years. Atmospheric carbon dioxide (Monnin et al. 2004), methane (Blunier et al. 1995; Flückiger et al. 2002) and nitrogen dioxide (Flückiger et al. 2002) concentrations and obliquity component of the full orbital solution (Laskar et al. 2004) for each simulation representing a snapshot every 250 years of the last 6000 . All other parameters are kept the same as the standard pre-industrial simulation

Asian region (Fig. 12.3). These simulated dry mid-Holocene climates are punctuated by short-lived periods that are significantly wetter, although still dryer than the preindustrial simulation. The latest of these occurs at approximately $1500 \mathrm{BCE}$ and its demise may be contemporaneous with climate drying in Mycenaean Greece and Hittite Anatolia associated with the Late Bronze Age Collapse (Kaniewski et al. 2013), but quickly (in approximately 500 years) returns to typical early Holocene values.

As well as precipitation change over the Holocene, other parameters have also changed, such as temperature. However, the change in precipitation in this region seems to dominate the water availability, as measured by simulated precipitationevaporation (Fig. 12.4). The ensemble seems to show a clear transition from the dryer climates of the middle Holocene to wetter climates of the late Holocene between 1000 and $250 \mathrm{BCE}$ (Fig. 12.3). In common with the drying following the $1500 \mathrm{BCE}$ event, the simulated increase in precipitation is strongest in the central Asian region, particularly in the area covered by the main classical Silk Road cities, from Merv to Kashgar (Fig. 12.5).

In the steppe region of Asia, through which East-West trade originally occurred on the Northern Route, no significant trend in Holocene precipitation is simulated (e.g. Fig. 12.5). Water resources are more plentiful in this region throughout the Holocene, but this means there has been neither the drive to urbanization and centralization of aridifying conditions or a significant increase in hydrological resources to create an elite class of wealthy individuals.

The response in the central Asian arid regions is in contrast to much of the ancient world, where civilizations were built in the great river valleys of the monsoonal 


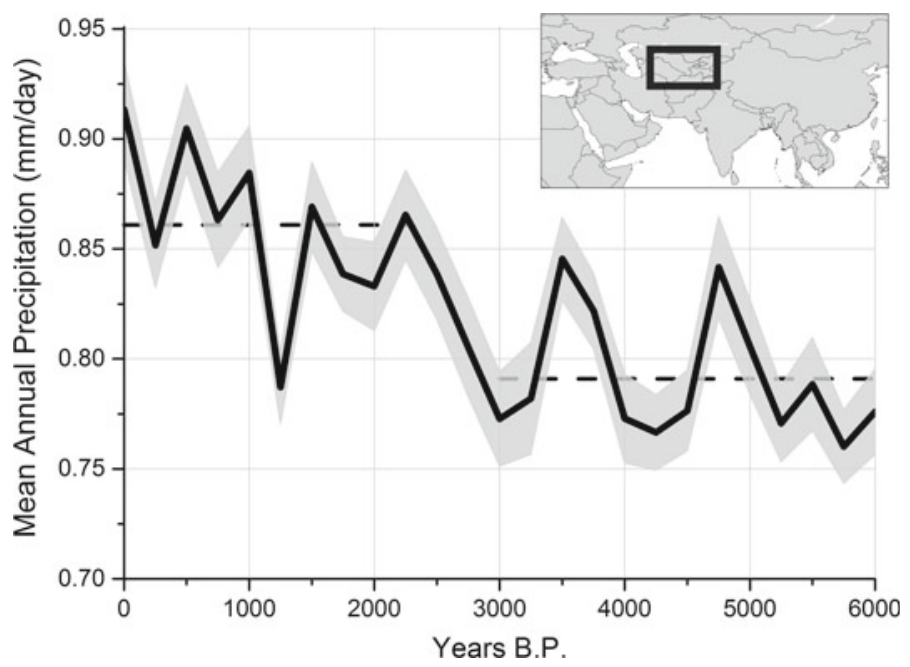

Fig. 12.3 Average mean annual precipitation over the central Asian region $\left(35^{\circ}-45^{\circ} \mathrm{N}\right.$, $56.25^{\circ}-75^{\circ} \mathrm{E}$ ) for each of the simulations for the last 6000 years. Shading shows the standard error for the average, with the area over which precipitation is averaged shown in the inset map. Dashed horizontal lines show the mean of the simulations up to 3000 years B.P. and after 2250 years B.P

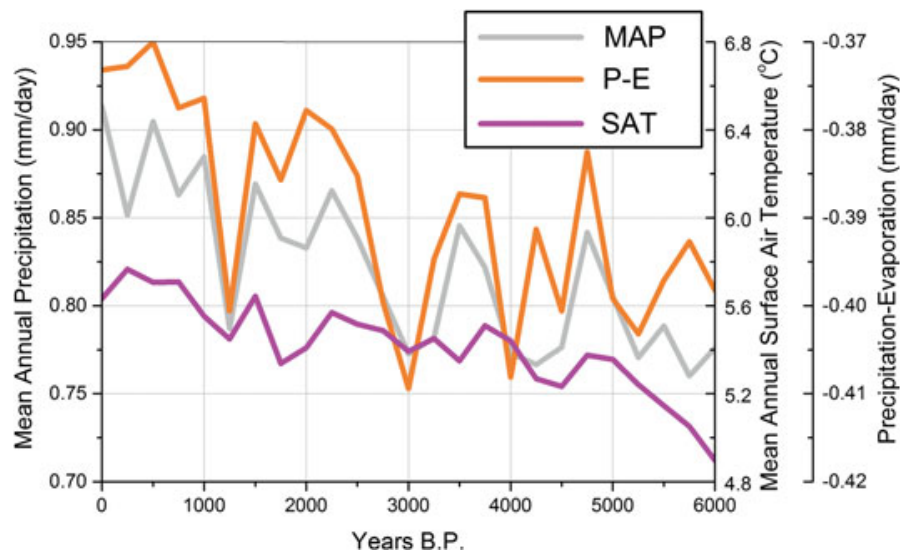

Fig. 12.4 Average mean annual precipitation (MAP; grey), precipitation minus evaporation (P$\mathrm{E}$; orange) and surface air temperature (SAT; magenta) over the central Asian region $\left(35^{\circ}-45^{\circ} \mathrm{N}\right.$, $56.25^{\circ}-75^{\circ} \mathrm{E}$ ) for each of the simulations for the last 6000 years

regions (Macklin and Lewin 2015) and hence were susceptible to the reduction in monsoons through the Holocene. Central Asian increases in rainfall are not linked to the monsoonal rains, but rather are produced by changes in the winter Western Disturbance weather systems, which provide the bulk of the annual rainfall in the region (Syed et al. 2006). Previous suggestions of the driving mechanisms of 
(a)

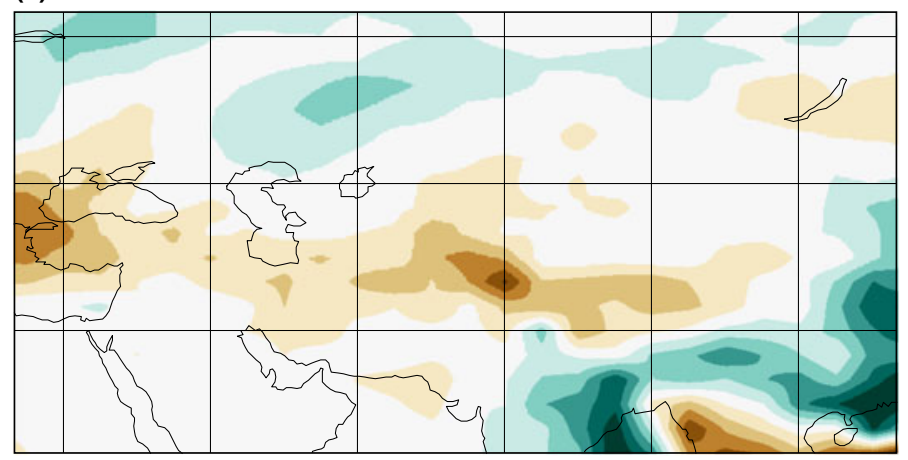

(b)

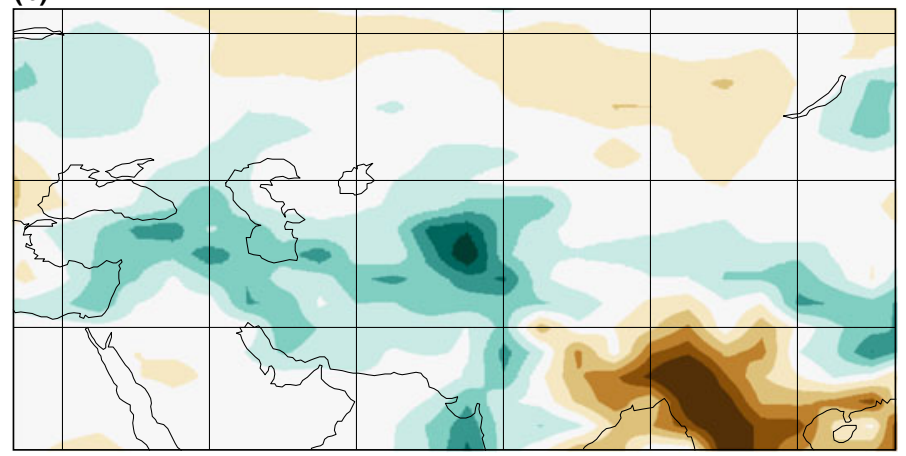

Precipitation change $(\mathrm{mm} /$ day $)$

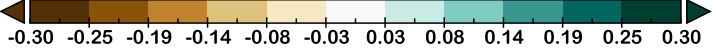

Fig. 12.5 Spatial patterns of modelled precipitation changes between 1500 and $1250 \mathrm{BCE}$ (a) and the transition that occurs between 1000 and $250 \mathrm{BCE}(\mathbf{b})$. Precipitation changes in central Asia are focussed on the area of interest (Fig. 12.2), although the link to other areas varies over time. For example, the pattern of change in Indian monsoon region and the Eastern Mediterranean is different between $\mathbf{a}$ and $\mathbf{b}$

variations in Western Disturbances, based on observational datasets, include changes in Icelandic Low related to NAO (North Atlantic Oscillation) or the Siberian High related to ENSO (El Niño Southern Oscillation).

Although there are times when changes in these pressure systems correlate with central Asian precipitation, particularly the Icelandic Low over the last millennium, for much of the last 6000 years the changes are decoupled. HadCM3 has previously been shown not to represent the teleconnections between ENSO and the monsoon systems (Turner et al. 2005), which may explain some of this decoupling. However, these simulations show changes in central Asian precipitation are related most closely to the contrast in Himalayan and Mediterranean pressure (Fig. 12.6). As these regions respectively represent the locations where the Western Disturbances initiate and ultimately disburse, the forcing mechanisms from these mean pressure features are clear. 


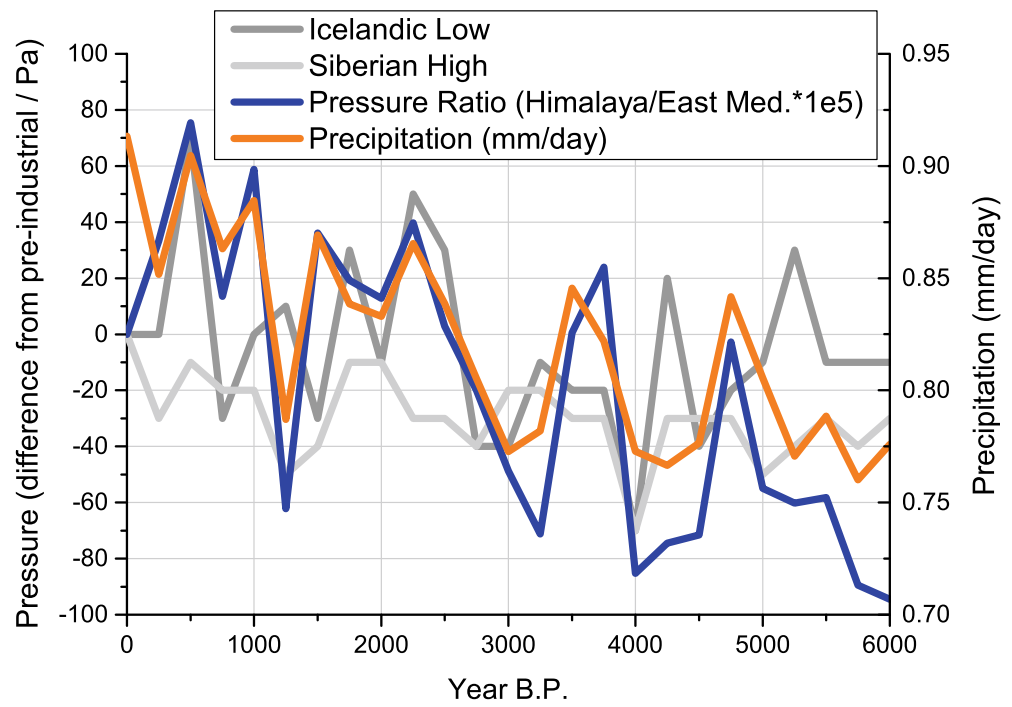

Fig. 12.6 Comparison of variations in central Asian dry region precipitation and selected pressure variables over the last 6000 years. Shown are the differences in the strength of the Icelandic Low, the Siberian High and pressure ratio of the Himalayan Low and the East Mediterranean High (H/M*1e5). The Icelandic Low system is related to North Atlantic Oscillation (NAO) and the Siberian High has been suggested to mediate the impact of El Niño Southern Oscillation (ENSO) on central Asian precipitation (Syed et al. 2006)

\subsection{Discussion}

The best Holocene palaeoenvironmental records of continental precipitation tend to come from large lakes and speleothems. As such there are few palaeoenvironmental records that track the precipitation in the central Asian arid regions (Chen et al. 2008), particularly in the region where changes are seen in these simulations (Fig. 12.5). However, a recently published speleothem record from Fergana Basin, shows a similar transition in precipitation inferred from oxygen isotopes (Wolff et al. 2017). As well as showing the shift at approximately the same time as the model, the general dynamics of precipitation in the region closely resemble that seen in the model, although the temporal resolution of the simulations does not allow for us to closely compare these with the data. Furthermore, the record from Lake Issyk-Kul in Kyrgyzstan, which is close to the eastern end of the Silk Roads, shows a significant change in sediment composition at around 3000 years B.P. This change is associated with a shift towards wetter taxa in the pollen record (Rasmussen et al. 2001). These changes are not reproduced in other records from the margin or outside of the region in which precipitation changes were simulated, including the Aral Sea (Ferronskii et al. 2003; Huang et al. 2011), Lake Karakul, Tajikistan (Mischke et al. 2010), Lake Balikun (An et al. 2011), Wulunga Lake (Jiang et al. 2007), Lop Nur (Mischke et al. 
2017), Lake Karakuli (Aichner et al. 2015), China or the Chinese Loess plateaux (Zhang et al. 2013).

There seem to be significant changes in precipitation in central Asia over the Holocene, which are linked to changes in the Western Disturbances, driven by variations in the Himalayan Low-East Mediterranean High pressure contrast. Although significant changes in precipitation and P-E are simulated within this modelling framework, increased resolution in the atmosphere model, could greatly improve the signal and spatial definition of the climatic changes. Moving to transient simulation of Holocene climate would give better temporal coverage, rather than relying on equilibrium climate response to snapshot climate forcing. This study has shown the changes in regional climate associated with the largest forcing of Holocene climate change, namely greenhouse gases and orbital forcing, but could be further extended by incorporating changes in volcanic forcing (Kobashi et al. 2017), solar variability (Steinhilber et al. 2012) and Himalayan glacial coverage (Solomina 2015).

Although there remain many questions as to how ancient cultures responded to climate changes, it appears that there are concurrent changes in Holocene climate and cultural developments in the region (Fig. 12.7). The period in which Late Bronze Age (LBA) cultures declined and the initial drive towards urbanisation are associated with climate deterioration from a short period of high precipitation around 1500 BCE. While the current imprecise timings of the loss of the Bronze Age cultures and the climate changes mean that causal relationships cannot be tested, the fact that significant changes in precipitation are simulated during this interval (Fig. 12.7) adds weight to the suggestion that climate may be involved (Salvatori 2008). The major cities of Samarkand and Bukhara were founded in this period, while some of the other classical Silk Road cities were founded in the final centuries BCE. A drying climate may have forced the founding of cities and initiation of large scale irrigation (Malatesta et al. 2012), however, the increased hydrological resources may have ultimately allowed these cities to flourish and provide the backbone of the Silk Road trade routes.

Although central Asia is particularly susceptible to changes in the extent that the Western Disturbance weather systems penetrate into Asia, changes in other parameters of these systems could have significant implications for other climate-human interactions across the Levant, Mesopotamia and into the Indian Subcontinent (Syed et al. 2006). Different regions and weather systems respond in different ways to the changes in Holocene forcings. Each civilization has its own technological development and ways of utilizing hydrological resources and thus to really understand the connection between societal adaptation and changing climate requires collaboration between palaeoclimate scientists and archaeologists.

\subsection{Conclusions}

Novel climate model simulations of the last 6000 years show significant shifts in central Asian precipitation. Of particularly note is the transition to wetter climates 


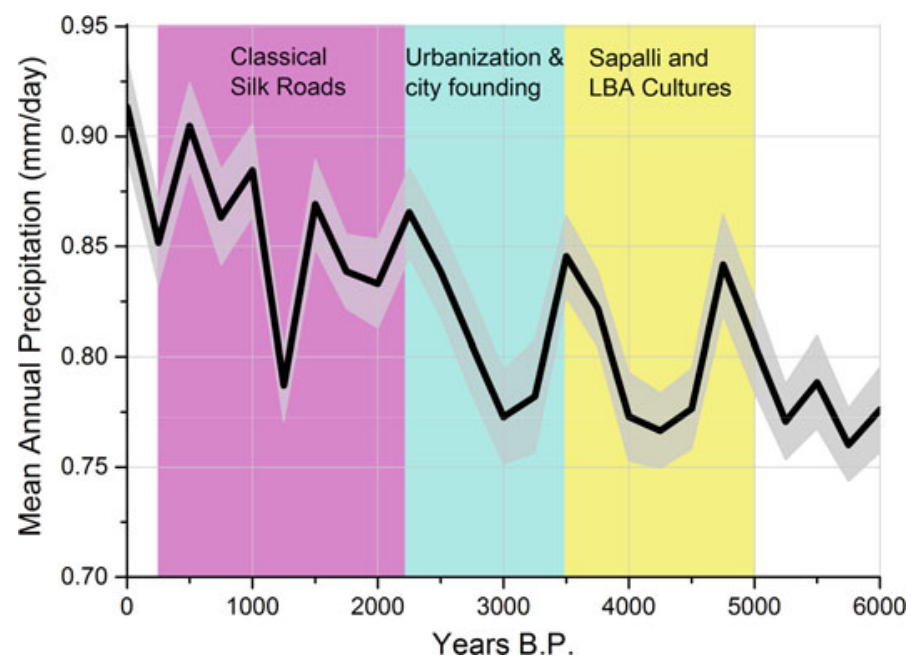

Fig. 12.7 Comparison of average annual mean precipitation over the central Asian dry region $\left(35^{\circ}-45^{\circ} \mathrm{N}, 56.25^{\circ}-75^{\circ} \mathrm{E}\right)$ for each of the simulations for the last 6000 years (Fig. 12.2) and cultural development of the central Asian region. Times of the classical Silk Roads correspond to increased hydrological resources, while period of urbanization began as climate deteriorated from a temporary high, before a time of increasing precipitation

that is simulated to occur between 1000 and 250 BCE. This coincides with the founding of the great cities of central Asia and the rise of the classical Silk Road trade routes through the region. While much more work is required to understand the impacts of this climate changes and the cultural responses to these, this study provides a provocation to explore these relationships in greater detail.

Acknowledgements These climate modelling simulations were undertaken on the ARC (Advanced Research Computing) facilities, part of the High Performance Computing at the University of Leeds, UK.

\section{References}

Aichner, B., Feakins, S. J., Lee, J. E., Herzschuh, U., \& Liu, X. (2015). High-resolution leaf wax carbon and hydrogen isotopic record of the late Holocene paleoclimate in arid Central Asia. Climate of the Past, 11, 619-633.

An, C.-B., Lu, Y., Zhao, J., Tao, S., Dong, W., Li, H., et al. (2011). A high-resolution record of Holocene environmental and climatic changes from Lake Balikun (Xinjiang, China): Implications for central Asia. The Holocene, 22, 43-52.

Anderson, A., Chappell, J., Gagan, M., \& Grove, R. (2006). Prehistoric maritime migration in Pacific Islands: An hypothesis of ENSO forcing. The Holocene, 16, 1-6.

Blunier, T., Chappellaz, J., Schwander, J., Stauffer, B., \& Raynaud, D. (1995). Variations in atmospheric methane concentration during the Holocene epoch. Nature, 374, 46-49. 
Braconnot P., Harrison, S. P., Joussaume, S., Hewitt, C. D., Kitoch, A., Kutzbach, J. E., Liu, Z., OttoBliesner, B., Syktus, J., \& Weber, S. L. (2004). Evaluation of PMIP coupled ocean-atmosphere simulations of the Mid-Holocene. In R. W. Battarbee, F. Gasse, C. E. Stickley (Eds.), Past climate variability through Europe and Africa. Developments in paleoenvironmental research (vol. 6). Dordrecht: Springer.

Braconnot, P., Harrison, S. P., Kageyama, M., Bartlein, P. J., Masson-Delmotte, V., Abe-Ouchi, A., et al. (2012). Evaluation of climate models using palaeoclimatic data. Nature Climate Change, 2, 417-424.

Büntgen, U., Tegel, W., Nicolussi, K., McCormick, M., Frank, D., Trouet, V., et al. (2011). 2500 years of European climate variability and hu, man susceptibility. Science, 331, 578-582.

Butzer, K. W. (2012). Collapse, environment and society. Proceedings of the National Academy of Sciences of the United States of America, 109, 3632-3639.

Cattani, M. (2008). The final phase of the bronze age and the "Andronovo Question in Margiana". In S. Salvatori \& M. Tosi (Eds.), The bronze age and early iron age in the Margiana Lowlands, BAR international series 1806 (pp. 133-148). Oxford: Archaeopress.

Chen, F., Yu, Z., Yang, M., Ito, E., Wang, S., Madsen, D. B., et al. (2008). Holocene moisture evolution in arid central Asia and its out-of-phase relationship with Asian monsoon history. Quaternary Science Reviews, 27, 351-364.

Christian, D. (2000). Silk roads or steppe roads? The silk roads in world history. Journal of World History, 11, 1-26.

Cox, M. D. (1984). A primitive equation, 3 dimensional model of the ocean. GFDL Ocean Group Technical Report 1, Princeton NJ, USA, p. 143.

Cox, P. (2001). Description of the TRIFFID dynamic global vegetation model. Hadley Centre Technical Report 24. Bracknell, UK: UK Met Office.

Dash, S. K., Kulkarni, M. A., Mohanty, U. C., \& Prasad, K. (2009). Changes in the characteristics of rain events in India. Journal of Geophysical Research, 114, D10109. https://doi.org/10.1029/ 2008JD010572.

Dong, G., Jia, X., An, C., Chen, F., Zhao, Y., Tao, S., et al. (2012). Mid-Holocene climate change and its effect on prehistoric cultural evolution in eastern Qinghai Province, China. Quaternary Research, 77, 23-30.

Drake, B. L. (2012). The influence of climatic change on the late bronze age collapse and the greek dark ages. Journal of Archaeological Science, 39, 1862-1870.

Faroqhi, S. (1994). Crisis and change, 1590-1699. In I. Halil, \& D. Quataert (Eds.), An economic and social history of the ottoman empire, 1300-1914 (p. 505). Cambridge University Press.

Ferronskii, V. I., Polyakov, V. A., Brezgunov, V. S., Vlasova, L. S., Karpychev, Y. A., Bobkov, A. F., et al. (2003). Variations in the hydrological regime of Kara-Bogaz-Gol Gulf, Lake Issyk-Kul and the Aral Sea assessed based on data of bottom sediment studies. Water Resources, 30, 252-259.

Flückiger, J., Monnin, E., Stauffer, B., Schwander, J., \& Stocker, T. F. (2002). High-resolution Holocene $\mathrm{N}_{2} \mathrm{O}$ ice core record and its relationship with $\mathrm{CH}_{4}$ and $\mathrm{CO}_{2}$. Global Biogeochemical Cycles, 16, 1. https://doi.org/10.29/2001gb001417.

Gordon, C., Cooper, C., Senior, C. A., Banks, H., Gregory, J. M., Johns, T. C., et al. (2000). The simulation of SST, sea ice extents and ocean heat transports in a version of the Hadley Centre coupled model without flux adjustments. Climate Dynamics, 16, 147-168.

Gregory, D., \& Morris, D. (1996). The sensitivity of climate simulations to the specification of mixed phase clouds. Climate Dynamics, 12, 641-651.

Gregory, D., Kershaw, R., \& Inness, P. M. (1997). Parametrisation of momentum transport by convection II: Test in a single column and general circulation model. Quarterly Journal of the Royal Meteorological Society, 123, 1153-1183.

Gregory, D., Shutts, G. J., \& Mitchell, J. R. (1998). A new gravity wave drag scheme incorporating anisotropic orography and low level wave breaking: Impact upon the climate of the UK Meteorological Office Unified Model. Quarterly Journal of the Royal Meteorological Society, 124, 463-493.

Grenet, F. (2002). Samarkand I. History and Archeology. Encyclopaedia Iranica. Online edition. 
Harrison, S. P., Bartlein, P. J., Brewer, S., Prentice, I. C., Boyd, M., Hessler, I., et al. (2014). Climate model benchmarking with glacial and mid-Holocene climates. Climate Dynamics, 43, 672-688. Herrmann, G. (1968). Lapis Lazuli: The early phases of its trade. Iraq, 30, 21-57.

Huang, X., Oberhänsli, H., von Suchodoletz, H., \& Sorrel, P. (2011). Dust deposition in the Aral Sea: Implications for changes in atmospheric circulation in central Asia during the past 2000 years. Quaternary Science Reviews, 30, 3661-3674.

Inness, P. M., \& Slingo, J. M. (2003). Simulation of the Madden-Julian oscillation in a coupled general circulation model. Part I: Comparison with observations and an atmosphere-only GCM. Journal of Climate, 16, 345-364.

Jiang, Q., Shen, J., Liu, X., Zhang, E., \& Xiao, X. (2007). A high-resolution climatic change since Holocene inferred from multi-proxy of lake sediment in westerly area of China. Chinese Science Bulletin, 52, 1970-1979.

Kaniewski, D., Van Campo, E., Guiot, J., Le Burel, S., Otto, T., \& Baeteman, C. (2013). Environmental roots of the late bronze age crisis. PLOS ONE, 8(e71004), 17.

Kaniuth, K. (2007). The metallurgy of the late bronze age sapalli culture (southern Uzbekistan) and its implications for the 'tin question'. Iranica Antiqua, 17, 23-40.

Kennett, D. J., Breitenbach, S. F. M., Aquino, V. V., Asmerom, Y., Awe, J., Baldini, J. U. L., et al. (2012). Development and disintegration of Maya political systems in response to climate change. Science, 338, 788-791.

Kobashi, T., Menviel, L., Jeltsch-Thömmes, A., Vinther, B. M., Box, J. E., Muscheler, R., Nakaegawa, T., Pfister, P. L., Döring, M., Leuenberger, M., Wanner, H., \& Ohmura, A. (2017). Volcanic influence on centennial to millennial Holocene Greenland temperature change. Scientific Reports, 7, Article number: 1441.

Lamberg-Karlovsky, C. C. (2013). The oxus civilization. Cuadernos de Prehistoria y Arqueologia Univeridad Autonoma de Madrid, 39, 21-63.

Laskar, J., Robutel, P., Joutel, F., Gastineau, M., Correia, A. C. M., \& Levrard, B. (2004). A longterm numerical solution for the insolation quantities of the earth. Astronomy \& Astrophysics, 428 , 261-285.

Lo Muzio, C. (2009). An archaeological outline of the Bukhara Oasis. Journal of Inner Asian Art and Archaeology, 4, 43-68.

Macklin, M. G., \& Lewin, J. (2015). The rivers of civilization. Quaternary Science Reviews, 114, 228-244.

Malatesta, L. C., Castelltort, S., Mantellini, S., Picotti, V., Hajdas, I., Simpson, G., et al. (2012). Dating the irrigation system of the Samarkand Oasis: A geoarchaeological study. Radiocarbon, 54, 91-105.

Mayewski, P. A., Rohling, E. E., Stager, J. C., Karlén, W., Maasch, K. A., Meeker, L. D., et al. (2004). Holocene climate variability. Quaternary Research, 62, 243-255.

McMahon, T. A., Peel, M. C., \& Karoly, D. J. (2015). Assessment of precipitation and temperature data from CMIP3 global climate models for hydrological simulation. Hydrology and Earth System Sciences, 19, 361-377.

McNeill, W. H. (1998). World history and the rise and fall of the West. Journal of World History, 9, 215-236.

Milton, S. F., Wilson, C. A. (1996). The impact of parameterized subgrid-scale orographic forcing on systematic errors in a global NWP model. Monthly Weather Review, 124, 2023-2045.

Mischke, S., Rajabov, I., Mustaeva, N., Zhang, C., Herzschuh, U., Boomer, I., et al. (2010). Modern hydrology and late Holocene history of Lake Karakul, eastern Pamirs (Tajikistan): A reconnaissance study. Palaeogeography, Palaeoclimatology, Palaeoecology, 289, 10-24.

Mischke, S., Liu, C., Zhang, J., Zhang, C., Zhang, H., Jiao, P., et al. (2017). The world's oldest Aral Sea type disaster: The decline of the Loulan Kingdom in the Tarim Basin. Scientific Reports, 7, 43102. https://doi.org/10.1038/srep43102.

Monnin, E., Steig, E. J., Siegenthaler, U., Kawamura, K., Schwander, J., Stauffer, B., et al. (2004). Evidence for substantial accumulation rate variability in Antarctica during the Holocene, through 
synchronization of $\mathrm{CO}_{2}$ in the Taylor Dome, Dome $\mathrm{C}$ and DML ice cores. Earth and Planetary Science Letters, 224, 45-54.

Olson, D. M., Dinerstein, E., Wikramanayake, E. D., Burgess, N. D., Powell, G. V. D., Underwood, E. C., D'amico, J. A., Itoua, I., Strand, H. E., Morrison, J. C., Loucks, C. J., Allnutt, T. F., Ricketts, T. H., Kura, Y., Lamoreux, J. F., Wettengel, W. W., Hedao, P., \& Kassem, K. R. (2001). Terrestrial ecoregions of the world: A new map of life on earth: A new global map of terrestrial ecoregions provides an innovative tool for conserving biodiversity. BioScience, 51, 933-938.

Rasmussen, K. A., Ricketts, R. D., Johnson, T. C., Romanovsky, V. V., \& Grigina, O. M. (2001). An 8,000 year multi-proxy record from Lake Issyk-Kul, Kyrgyzstan. PAGES News, 9, 5-6.

Ridley, J., Wiltshire, A., \& Mathison, C. (2013). More frequent occurrence of westerly disturbances in Karakoram up to 2100. Science of the Total Environment, 468-469, S31-S35.

Salvatori, S. (2008). The Margiana settlement pattern from the middle bronze age to the PartianSasanian period: A contribution to the study of complexity. In S. Salvatori \& M. Tosi (Eds.), The bronze age and early iron age in the Margiana Lowlands, BAR international series 1806 (pp. 133-148). Oxford: Archaeopress.

Solomina, O. N., Bradley, R. S., Hodgson, D. A., Ivy-Ochs, S., Jomelli, V., Mackintosh, A. N., et al. (2015). Holocene glacier fluctuations. Quaternary Science Reviews, 111, 9-34.

Staubwasser, M., Sirocko, F., Grootes, P. M., \& Segl, M. (2003). Climate change at the $4.2 \mathrm{ka}$ $\mathrm{BP}$ termination of the Indus valley civilization and Holocene south Asian monsoon variability. Geophysical Research Letters, 30, 1425. https://doi.org/10.1029/2002g1016822.

Steinhilber, F., Abreu, J. A., Beer, J., Brunner, I., Christl, M., Fischer, H., et al. (2012). 9,400 years of cosmic radiation and solar activity from ice cores and tree rings. Proceedings of the National Academy of Sciences of the United States of America, 109, 5967-5971.

Syed, F. S., Giorgi, F., Pal, J. S., \& King, M. P. (2006). Effect of remote forcings on the winter precipitation of central southwest Asia part 1: Observations. Theoretical and Applied Climatology, 86, 147-160.

Turner, A. G., Inness, P. M., \& Slingo, J. M. (2005). The role of the basic state in the ENSO-monsoon relationship and implications for predictability. Quarterly Journal of the Royal Meteorological Society, 131, 781-804.

Welc, F., \& Marks, L. (2014). Climate change at the end of the Old Kingdom in Egypt around 4200 BP: New geoarchaeological evidence. Quaternary International, 324, 124-133.

Wolff, C., Plessen, B., Dudashvilli, A. S., Breitenbach, S. F. M., Cheng, H., Edwards, L. R., et al. (2017). Precipitation evolution of Central Asia during the last 500 years. The Holocene, 27, $142-154$.

Zhang, W., Shi, Z., Chen, G., Liu, Y., Niu, J., Ming, Q., et al. (2013). Geochemical characteristics and environmental significance of Talede loess-paleosol sequences of Ili Basin in Central Asia. Environmental Earth Sciences, 70, 2191-2202.

Open Access This chapter is licensed under the terms of the Creative Commons Attribution 4.0 International License (http://creativecommons.org/licenses/by/4.0/), which permits use, sharing, adaptation, distribution and reproduction in any medium or format, as long as you give appropriate credit to the original author(s) and the source, provide a link to the Creative Commons license and indicate if changes were made.

The images or other third party material in this chapter are included in the chapter's Creative Commons license, unless indicated otherwise in a credit line to the material. If material is not included in the chapter's Creative Commons license and your intended use is not permitted by statutory regulation or exceeds the permitted use, you will need to obtain permission directly from the copyright holder.

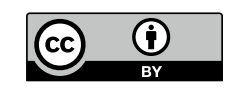

